\title{
Economic Growth and Internet Usage Impact on Publication Productivity among ASEAN's and World's Best Universities
}

\author{
Hossein Gholizadeh ${ }^{1}$, Hadi Salehi ${ }^{2}$, Mohamed Amin Embi ${ }^{3}$, Mahmoud Danaee ${ }^{4}$, Ali Ordi ${ }^{5}$, Farid Habibi Tanha ${ }^{6}$, \\ Nader Ale Ebrahim ${ }^{7} \&$ Noor Azuan Abu Osman ${ }^{1}$ \\ ${ }^{1}$ Department of Biomedical Engineering, Faculty of Engineering, University of Malaya, 50603 Kuala Lumpur, \\ Malaysia \\ ${ }^{2}$ Faculty of Literature and Humanities, Najafabad Branch, Islamic Azad University, Najafabad, Isfahan, Iran \\ ${ }^{3}$ Faculty of Education, Universiti Kebangsaan Malaysia, Bangi, 43600, Malaysia \\ ${ }^{4}$ Faculty of Agriculture, Roudehen Branch, Islamic Azad University, Roudehen, Iran \\ ${ }^{5}$ Universiti Teknologi Malaysia, Advance Informatics School (AIS), Kuala Lumpur, Malaysia \\ ${ }^{6}$ Department of Financial Sciences, University of Economic Sciences, Tehran, 1593656311, Iran \\ ${ }^{7}$ Research Support Unit, Centre of Research Services, Institute of Research Management and Monitoring (IPPP), \\ University of Malaya, Malaysia \\ Correspondence: Hadi Salehi, Faculty of Literature and Humanities, Najafabad Branch, Islamic Azad University, \\ Najafabad, Isfahan, Iran. E-mail: hadisalehi1358@yahoo.com
}

Received: July 3, $2014 \quad$ Accepted: July 21, $2014 \quad$ Online Published: September 1, 2014

doi:10.5539/mas.v8n5p169 URL: http://dx.doi.org/10.5539/mas.v8n5p169

\begin{abstract}
Measuring the number of papers which are published each year, publication productivity is the factor which shows the reputation of universities and countries. However, the effect of growing economy and using internet on the publication productivity in Asian countries has not been discovered yet. The present research is going to figure out the publication productivity among the elite universities in Asian countries and also ten top universities around the world in the last twenty years (from 1993 to 2012). Furthermore, the current research is aimed to study the relationship among publication, gross domestic product (GDP) and internet usage. It is worth to mention that the publication of the top Ten Malaysian Universities was regarded for the similar period of time. To get the exact numbers of documents like papers, conference articles, review papers and letters which are published by the universities in the last twenty years, the writer of the same paper used the Science Direct database. Moreover, the data for GDP and the number of internet usage was collected through the World Bank database (World Data Bank).To compare all kinds of publications,one-way ANOVAwas used and to investigate the impact of economic growth and internet usageon publication productivity, multiple regression analysis was applied.The results showed that therate of publication growth was 1.9, 20.9, and $65.5 \%$ in top universities in the world, ASEAN countries and Malaysia, respectively.The results also showed thatthere was a positive and significant correlationbetween GDP and the number of internet users with the number of publications in ASEAN and Malaysian universities. Internet usagehad much more influence in comparison withthe GDP in predicting the number of publicationsamong these groups except for top ten Malaysian universities from 2003 to 2012. In summary, publication trends in top ten Malaysian and ASEAN universities are promising. However, policy makers and science managersshouldspend much more percentage of their GDP on Internet facilities and research studies that their outputs lead to more rapid economic growthand internet usage.
\end{abstract}

Keywords: ASEAN, publication productivity, documents, internet usage, GDP, Malaysian Universities, publication trend

\section{Introduction}

Ten countries in Southeast Asia formed the geo-political and economic Association of Southeast Asian Nations. It was first formed on 8 August 1967 by Indonesia, Malaysia, the Philippines, Singapore and Thailand. Some other countries like Brunei, Burma (Myanmar), Cambodia, Laos, and Vietnam became the members of this group and expanded it. The chief purpose of organizing this group is increasing economic growth (Sarel, 1997). 
Gross domestic product (GDP) which refers to the market price of all officially realized goods and services which are produced in a country in a specific period of time is the chief tool to measure the economy of a country. Reviewing the previously published papers, the writer found out that there is a relationship between economic growth with education and paper publication. The above mentioned result is not fully support by realistic facts (Jin, 2013; Nelson, 1966; Lucas Jr, 1988; Becker, 2009; Romer, 1990). Positive and significant impact of education on economic growth has been found by Mankiw et al. (1992) and Barro (1991) (Mankiw et al., 1992 \& Barro, 1991); however, a possibility of reverse relationship between economic growth and education was shown by Bils and Klenow (2000). Besides, Jin and Jin newly indicated that the effect of publication productivity on economic growth is not the same in different fields. For example, there is a positive relationship between engineering and science with economic growth, while the social sciences do not have the same effect on economic growth (Jin, 2013).

Nowadays, compared with the past twenty years, studying the publication productivity is a main topic for the researchers and students because the findings of the researches can positively affect the whole community Zain et al., 2009). According to the recent development rules, the numbers of educated employees have been enhanced. This matter helps the economy of the countries to grow very fast (Jin, 2013). It has been found out that those countries which are highly developed like the United Stated and England are among the world's top productive research universities. The number of publication shows the research productivity and is employed to grade the countries and universities (Yazit and Zainab, 2007, Narin and Hamilton, 1996, Toutkoushian et al., 2003, Liu and Cheng, 2005, Meho and Spurgin). It can also be used to determine author's productivity or the publication productivity of research groups (Liu, 2005; Hart, 2000; Uzun, 2002; Gu, 2001; Fox, 1983). Numerously referring to the previously published papers by the new papers a lot, shows the following identification and also the effect in the field of study. Those review articles which refer to other articles a lot, can give us some facts about the major areas of discipline besides, they can emphasize the increase of specific fields. Moreover, more frequently cited papers are mostly written by famous researchers who can impress future directions of the field by their ideas (Lefaivre and O'Brien, 2011, Kelly et al., 2010, Ponce and Lozano, 2010, Joynt and Leonard, 1980).

Several indicators of academic or research performance are used to rank educational institutes and universities. They includealumni and staff winning Nobel Prizes and Fields Medals, highly cited researchers, papers published in Nature and Science, papers indexed in major citation indices, and the per capita academic performance of an institution. The Academic Ranking of World Universities (ARWU) is the first global ranking of universities to be published. Today, ARWU is regarded to be one of the three most influential and widely observed international university rankings, along with the QS World University Rankings and the Times Higher Education World University Rankings. The Academic Ranking of World Universities (ARWU), commonly known as the Shanghai Ranking, is a publication that was founded and compiled by the Shanghai Jiao Tong University to rank universities globally. The rankings have been conducted since 2003 and updated annually.

The current study is mainly going to investigate the amount of publication productivity among the best universities in ASEAN countries and world's top ten universities from 1993 to 2002 and 2003 to 2012.The study also aimed to achieve the following objectives:

- Studying the relationship among publication productivity, gross domestic product (current US \$) and internet users

- Examining the publication direction of ten elite Malaysian Universities in a specific time periods

Since the Science Direct offers about 20\% more inclusion than Web of Science, it has been used as the first full-text theoretical database in this research. The researchers think that there is a positive relationship among the economic growth, the numbers of people who can use the internet and also the number of publication of papers in elite Asian universities and also the ten best universities in the whole world.

\section{Methodology}

ScienceDirect database was used to collect the number of documentsincluding articles, conference papers, review papers, letters and books published in the last two decades from 1993 to 2002 and 2003to 2012. These data were collectedto make a comparison among the top university in each ASEAN country, top tenuniversities in Malaysia andtop tenuniversities in the world. To find the first university in each ASEAN countryand top tenMalaysian universities, we used the number of publications in ScienceDirect database. Moreover,to determine the top tenuniversities in the world, the Academic Ranking of World Universities (ARWU) was used. Furthermore, in each university, the main subject area (overall), number of papers published in Nature and Science journals, and the most cited paperswere identified.The numbers of citations that eachpaper could receive 
during one week were identified as well.

To compare all kinds of publicationsamongtop ten universities in the world, ASEAN and Malaysia), one-way ANOVA was applied. As the homogeneity test was not met, the Welch statistic was used to test the equality of means. Moreover, to evaluate the relationship between publications (articles, conference papers, review papers, letters) with GDP and Internet usage, Spearman correlation coefficient test was applied.To investigate economic growth and internet use impact on publication productivity,multiple regression was applied to examine what extent the proposed multiple liner regression model is supported by the research data. The regression examined how well the number of publications could be predicted from GDP and internet usage.In the multiple regression model, GDP and Internet usagewere set as the independent variables and the number of publications was considered as the dependent variable.

\section{Results}

According to the Academic Ranking of World Universities (ARWU), the top tenuniversities in the world are mostly located in the United States (8 universities) or United Kingdom (2 universities) (see Table 1). Moreover, the first university in each ASEAN countryand top tenuniversities in Malaysia based on the number of publications in ScienceDirect database were listed in Table 1.The main research areas in world's best universities were physics andastronomy ( 7 universities), medicine ( 2 universities) and engineering ( 1 university). In these universities, the average number of papers published in Nature and Sciencewere 1586 and 1419, respectively (see Table 1).

Table 1. The average number of published papers

\begin{tabular}{|c|c|c|c|c|c|c|c|c|c|c|}
\hline \multirow{2}{*}{\multicolumn{2}{|c|}{ Institution (country) }} & \multirow{2}{*}{$\begin{array}{l}\text { established } \\
\text { (year) }\end{array}$} & \multirow{2}{*}{$\begin{array}{c}\text { Overall } \\
\text { publication* }\end{array}$} & \multirow{2}{*}{$\begin{array}{c}\text { Main } \\
\text { Subject area }\end{array}$} & \multirow{2}{*}{$\begin{array}{c}\text { Main } \\
\text { Subject } \\
\text { area (\% } \\
\text { publication) }\end{array}$} & \multirow{2}{*}{$\begin{array}{c}\text { papers } \\
\text { (Nature) }\end{array}$} & \multirow{2}{*}{$\begin{array}{c}\text { papers } \\
\text { (Science) }\end{array}$} & \multirow{2}{*}{$\begin{array}{c}\text { most } \\
\text { cited } \\
\text { paper } \\
\text { (citation) } \\
22 / 7 / 2013\end{array}$} & \multirow{2}{*}{$\begin{array}{c}\text { most } \\
\text { cited } \\
\text { paper } \\
\text { (citation) } \\
29 / 7 / 2013\end{array}$} & \multirow{2}{*}{$\begin{array}{c}\text { most cited } \\
\text { paper } \\
\text { (publication } \\
\text { date) }\end{array}$} \\
\hline & & & & & & & & & & \\
\hline \multirow{11}{*}{ 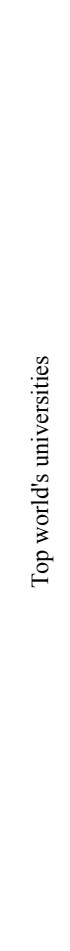 } & $\begin{array}{c}\text { Harvard University } \\
\text { (US) }\end{array}$ & 1636 & 74433 & $\begin{array}{l}\text { Physics and } \\
\text { Astronomy }\end{array}$ & 14.8 & 1430 & 2294 & 10224 & 10255 & 1990 \\
\hline & $\begin{array}{c}\text { Stanford University } \\
\text { (US) }\end{array}$ & 1891 & 110914 & Engineering & 13.6 & 861 & 1593 & 6249 & 6266 & 2001 \\
\hline & Massachusetts & & & & & & & & & \\
\hline & $\begin{array}{c}\text { Institute of } \\
\text { Technology (MIT) } \\
\text { (US) }\end{array}$ & 1861 & 134794 & $\begin{array}{l}\text { Physics and } \\
\text { Astronomy }\end{array}$ & 20.1 & 1563 & 1860 & 11678 & 11732 & 2000 \\
\hline & $\begin{array}{c}\text { University of } \\
\text { California, Berkeley } \\
\text { (US) }\end{array}$ & 1868 & 158231 & $\begin{array}{l}\text { Physics and } \\
\text { Astronomy }\end{array}$ & 15.3 & 1864 & 2233 & 18659 & 18757 & 1965 \\
\hline & $\begin{array}{c}\text { University of } \\
\text { Cambridge (UK) }\end{array}$ & 1209 & 135913 & $\begin{array}{l}\text { Physics and } \\
\text { Astronomy }\end{array}$ & 14.9 & 4099 & 644 & 7966 & 7977 & 1990 \\
\hline & $\begin{array}{l}\text { California Institute } \\
\text { of Technology (US) }\end{array}$ & 1891 & 62675 & $\begin{array}{l}\text { Physics and } \\
\text { Astronomy }\end{array}$ & 26.3 & 974 & 1134 & 8657 & 8705 & 1995 \\
\hline & $\begin{array}{c}\text { Princeton University } \\
\text { (US) }\end{array}$ & 1764 & 62273 & $\begin{array}{l}\text { Physics and } \\
\text { Astronomy }\end{array}$ & 20.1 & 754 & 945 & 6123 & 6136 & 1998 \\
\hline & $\begin{array}{c}\text { Columbia } \\
\text { University (US) }\end{array}$ & 1754 & 112569 & Medicine & 17.9 & 676 & 1403 & 10425 & 10484 & 1998 \\
\hline & $\begin{array}{l}\text { University of } \\
\text { Chicago (US) }\end{array}$ & 1890 & 90126 & Medicine & 21.7 & 980 & 1560 & 11741 & 11777 & 1953 \\
\hline & $\begin{array}{l}\text { University of } \\
\text { Oxford (UK) }\end{array}$ & 1096 & 122553 & $\begin{array}{l}\text { Physics and } \\
\text { Astronomy }\end{array}$ & 15.2 & 2658 & 526 & 10198 & 10216 & 2001 \\
\hline \multirow{3}{*}{ 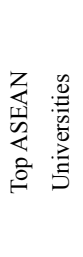 } & $\begin{array}{c}\text { National University } \\
\text { of Singapore } \\
\text { (Singapore) }\end{array}$ & 1905 & 74484 & Engineering & 17.9 & 71 & 0 & 2171 & 2180 & 2003 \\
\hline & $\begin{array}{c}\text { University of } \\
\text { Malaya (Malaysia) }\end{array}$ & 1949 & 21563 & Medicine & 14.9 & 24 & 0 & 445 & 449 & 2000 \\
\hline & Mahidol University & 1943 & 20291 & Medicine & 41.9 & 0 & 0 & 1494 & 1503 & 2005 \\
\hline
\end{tabular}


(Thailand)

Institut Teknologi

$$
\text { Bandung }
$$

(Indonesia)

International Rice

Research Institute

(Philippines)

Vietnam National

University

(Vietnam)

UNIVERSITI

BRUNEI

DARUSSALAM

(Brunei)

Institut Pasteur du

Cambodge

(Cambodia)

National University

of Laos (Laos)

University of

Yangon (Myanmar)

University of

$$
\text { Malaya }
$$

Universiti Sains

Malaysia

Universiti Putra

Malaysia

Universiti

Kebangsaan

Malaysia

UniversitiTeknologi

$$
\text { Malaysia }
$$

UniversitiTeknologi

$$
\text { MARA }
$$

International Islamic

University Malaysia

Multimedia

University

UniversitiTeknologi

Petronas

Universiti Malaysia
$1959 \quad 2979$

Engineering

23.6

0

Agricultural

$1960 \quad 2955$

1945

1230

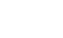

1985

864

1953

$$
251
$$

Medicine

44.9

Agricultural

and

1996

178

Biological

1878

109

1949

1962

(1969)

1969

16322

1970

15010

Chemistry

Medicine

Material

Science

Agricultural

and

Biological

Engineering

$1975 \quad 10134$

1956-1965 6784

1983

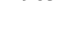

3995

$1996 \quad 3872$

1997

3343

2001

232

3.6

13.3

0

15.7

0

Engineering

Computer

23.5

science

32.6

Engineering

Perlis

(4)

$14.9 \quad 24 \quad 0$

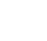

0

453

2004

$\begin{array}{llll}\text { Engineering } & 26.1 & 0 & 0\end{array}$

260

$\begin{array}{llll}\text { Engineering } & 22.5 & 0 & 0\end{array}$

$305 \quad 307$

$\begin{array}{lllll}\text { Engineering } & 19.8 & 0 & 0\end{array}$

101

2007

$0 \quad 0 \quad 275$

2001

0

0

77

2008

0

137

137

However, top universities in ASEAN countries could averagely publish 11 papers in Nature Journal and 2 papers in Science journal. The average numbers of citations for the most cited papers in each university in these three groups (world, ASEAN and Malaysia) were 10192, 660 and 331, respectively. Furthermore, the resultsshowed 39 citations per week for most cited papers in world's top universities while it was 4 citations per weekin ASEAN universities (see Table 1, Figure 1). 

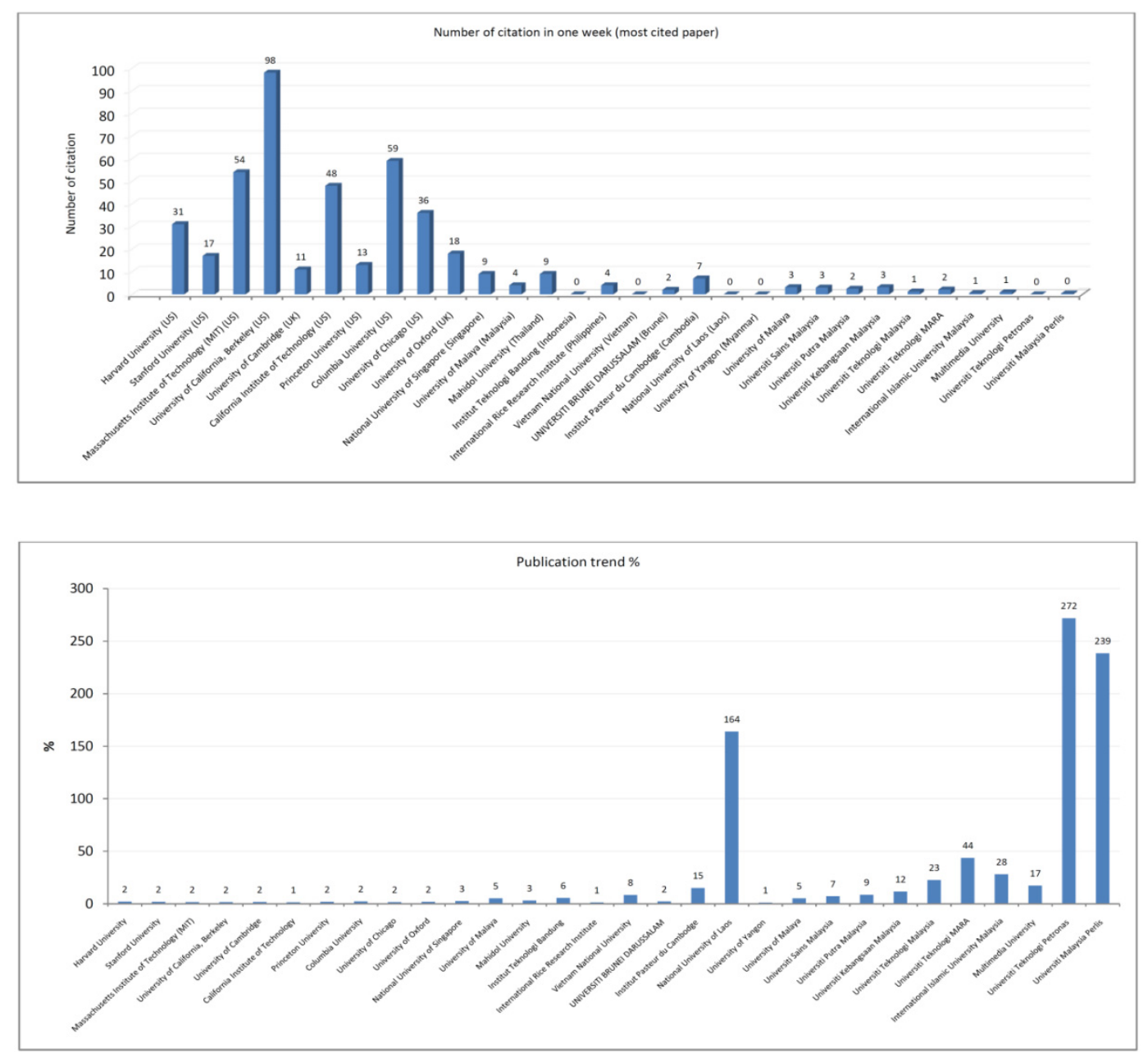

Figure 1. Number of citations in one week for the most cited papers in each university (Top); Publication trend

(Down)

University of Singapore with 74484 papers was the first in ASEAN countries and was followed by University of Malaya with 21563 publications among ASEAN countries. Moreover, the University of Yangon in Myanmar had the leastpublications (109) among ASEAN countries.Interestingly, publication trends in ASEAN countries are promising compared to the top ten universities in the world (see Appendixes 1 and 2).The rate of publication growth between these twodecades was 1.9, 20.9 and 65.5 percentagein top universities in the world, ASEAN and Malaysia, respectively (see Figure 1).

To compare all kinds of publications, the results of ANOVA showed that there were significant differences among these three groups. Duncan's multiple rangetest showed that there wasno significant difference between ASEAN and Malaysia universities, while both of them were significantly lower than top ten world universities (see Table 2).

Table 3 shows the correlation between indices (articles, conference papers, review papers, and letters), GDP and internet users for these three groups. The results showedthat there was a positive and significant correlationbetween GDP and the number of internet users with the number of publicationsin ASEAN and top ten Malaysian universities. However, there was a negative correlationbetween GDP and internet users with the number of letters published from 1993 to 2002 in Malaysia. Moreover, there was a negative and significant correlationbetween GDP and the number of articles published in world's top universities (see Table 3).

TheR-squared (R2) value presented in Table 4showed some information about the goodness of fit of a model. In regression, the R2 coefficient of determination is a statistical measure of how well the regression line approximates the real data points. TheR 2 of 1 indicates that the regression line perfectly fits the observeddata. 
TheR2value of 0.584 for ASEAN universities from 1993 to 2002 implies that the two-predictor model explained about $58.4 \%$ of the variance in publications. Table 5 revealed that based on the reported value of the F-statistic, the model fits the data. This means that the slope of the estimated linear regression model line was not equal to zero; thus, it confirmedthat there was a linear relationship between publication and the two-predictor variables.

Table 2. A (Welch robust Tests of Equality of Means); B (Pairwise comparison using Tamhane test)

(A)

\begin{tabular}{lcccccc}
\hline & \multicolumn{3}{c}{$\mathbf{1 9 9 3 - 2 0 0 2}$} & & \multicolumn{3}{c}{$\mathbf{2 0 0 3 - 2 0 1 2}$} \\
\hline & Welch statistic & $\mathrm{df}$ & $\mathrm{Sig}$. & Welch Statistic & df & Sig. \\
Article & 306.521 & 137.71 & $\mathrm{P}<0.05$ & 222.531 & 182.888 & $\mathrm{P}<0.05$ \\
Conference & 119.638 & 135.955 & $\mathrm{P}<0.05$ & 77.143 & 188.254 & $\mathrm{P}<0.05$ \\
Review & 159.91 & 142.948 & $\mathrm{P}<0.05$ & 221.178 & 160.595 & $\mathrm{P}<0.05$ \\
Letter & 143.944 & 168.747 & $\mathrm{P}<0.05$ & 101.268 & 156.708 & $\mathrm{P}<0.05$ \\
Total publication & 319.809 & 137.21 & $\mathrm{P}<0.05$ & 230.36 & 180.99 & $\mathrm{P}<0.05$ \\
\hline
\end{tabular}

$(\mathrm{B})^{*}$

\begin{tabular}{|c|c|c|c|c|c|c|}
\hline Decade & & Article & Conference & Review & Letter & $\begin{array}{c}\text { Total } \\
\text { publication } \\
\end{array}$ \\
\hline \multirow{3}{*}{ 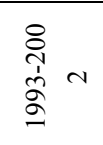 } & Top world & $2030.73 a$ & $264.1 \mathrm{a}$ & $124.6 \mathrm{a}$ & $23.93 \mathrm{a}$ & $2443.36 \mathrm{a}$ \\
\hline & ASEAN & $222.98 \mathrm{~b}$ & $28.76 \mathrm{~b}$ & $6.55 \mathrm{~b}$ & $1.65 \mathrm{~b}$ & $259.94 \mathrm{~b}$ \\
\hline & Malaysia & $66.58 \mathrm{c}$ & $8.87 \mathrm{~b}$ & $2.13 b$ & $0.78 \mathrm{~b}$ & $78.36 \mathrm{c}$ \\
\hline \multirow{3}{*}{ 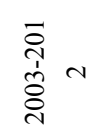 } & Top world & $3304.72 \mathrm{a}$ & $776.77 \mathrm{a}$ & $374.79 a$ & $58.3 \mathrm{a}$ & $4514.58 \mathrm{a}$ \\
\hline & ASEAN & $574.85 \mathrm{~b}$ & $166.54 \mathrm{~b}$ & $35 \mathrm{~b}$ & $7.04 \mathrm{~b}$ & $783.43 \mathrm{~b}$ \\
\hline & Malaysia & $509.03 \mathrm{~b}$ & $235.81 \mathrm{~b}$ & $22.39 b$ & $3.31 \mathrm{~b}$ & $770.54 b$ \\
\hline
\end{tabular}

Means with same letter are not significantly different in each column.

*data are log transformed.

Table 3. Correlation coefficient between the number of articles, conference papers, review papers and letters with GDP and internet usage for Top ten universities of the world, ASEAN and Malaysia

\begin{tabular}{|c|c|c|c|c|c|}
\hline & & \multicolumn{2}{|c|}{$1993-2002$} & \multicolumn{2}{|c|}{ 2003-2012 } \\
\hline & & GDP & internet & GDP & internet \\
\hline \multirow{4}{*}{ WOELD } & Article & -0.042 & $.229^{*}$ & -0.004 & $.531 * *$ \\
\hline & Conference & 0.178 & $.232 *$ & 0.012 & 0.158 \\
\hline & Review & 0.185 & $.497 * *$ & $-.443 * *$ & -0.062 \\
\hline & Letter & -0.128 & 0.137 & $-.256^{*}$ & $.324 * *$ \\
\hline \multirow{4}{*}{ ASEAN } & Article & $.723 * *$ & $.611 * *$ & $.779 * *$ & $.800 * *$ \\
\hline & Conference & $.775^{* *}$ & $.599 * *$ & $.737^{* *}$ & $.739 * *$ \\
\hline & Review & $.565 * *$ & $.574 * *$ & $.518^{* *}$ & $.705^{* *}$ \\
\hline & Letter & $.416^{* *}$ & $.416^{* *}$ & $.415^{* *}$ & $.567 * *$ \\
\hline \multirow{4}{*}{ MALAYSIA } & Article & 0.133 & $.280 * *$ & $.624 * *$ & $.595^{* *}$ \\
\hline & Conference & $.249 *$ & $.400 * *$ & $.879 * *$ & $.876^{* *}$ \\
\hline & Review & 0.09 & 0.171 & $.530^{* *}$ & $.442 * *$ \\
\hline & Letter & -0.03 & -0.008 & $.338 * *$ & $.258^{*}$ \\
\hline
\end{tabular}

\footnotetext{
**. Correlation is significant at the 0.01 level (2-tailed).

*. Correlation is significant at the 0.05 level (2-tailed).
} 
Table 4. Results of multiple linear regression between GDP and internet usage with total number of publications for Top ten universities of the world, ASEAN and Malaysia, respectively

\section{3-2002}

\begin{tabular}{|c|c|c|c|c|c|c|c|}
\hline \multirow[b]{2}{*}{ group } & & \multicolumn{2}{|c|}{ Unstandardized Coefficients } & \multirow{2}{*}{$\frac{\text { Standardized Coefficients }}{\text { Beta }}$} & \multirow[t]{2}{*}{$\mathbf{t}$} & \multirow[t]{2}{*}{ Sig. } & \multirow[t]{2}{*}{$\mathbf{R 2}$} \\
\hline & & B & Std. Error & & & & \\
\hline \multicolumn{8}{|c|}{ Top world } \\
\hline & GDP* & -1149.03 & 279.863 & -0.408 & -4.106 & $\mathrm{P}<0.05$ & 0.187 \\
\hline & internet & 21.03 & 4.943 & 0.423 & 4.254 & $\mathrm{P}<0.05$ & \\
\hline \multicolumn{8}{|c|}{ ASEAN } \\
\hline & GDP* & 197.843 & 70.785 & 0.214 & 2.795 & $\mathrm{P}<0.05$ & 0.584 \\
\hline & internet & 43.194 & 4.661 & 0.708 & 9.267 & $\mathrm{P}<0.05$ & \\
\hline \multicolumn{8}{|c|}{ Malaysia } \\
\hline & GDP* & 100.412 & 164.662 & 0.066 & 0.61 & 0.543 & 0.063 \\
\hline & internet & 1.771 & 0.888 & 0.216 & 1.994 & $\mathrm{P}<0.05$ & \\
\hline
\end{tabular}

* log transformed.

2003-2012

\begin{tabular}{|c|c|c|c|c|c|c|c|}
\hline & & \multicolumn{2}{|c|}{ Unstandardized Coefficients } & \multirow{2}{*}{$\begin{array}{c}\text { Standardized Coefficients } \\
\text { Beta }\end{array}$} & \multirow[t]{2}{*}{$\mathbf{t}$} & \multirow[t]{2}{*}{ Sig. } & \multirow[t]{2}{*}{$\mathbf{R 2}$} \\
\hline group & & B & Std. Error & & & & \\
\hline \multicolumn{8}{|c|}{ Top world } \\
\hline & GDP* & -1461.77 & 446.388 & -0.297 & -3.275 & $\mathrm{P}<0.05$ & 0.276 \\
\hline & internet & 121.544 & 25.935 & 0.425 & 4.687 & $\mathrm{P}<0.05$ & \\
\hline \multicolumn{8}{|c|}{ ASEAN } \\
\hline & GDP* & 363.724 & 161.614 & 0.177 & 2.251 & $\mathrm{P}<0.05$ & 0.551 \\
\hline & internet & 42.706 & 4.983 & 0.676 & 8.57 & $\mathrm{P}<0.05$ & \\
\hline \multicolumn{8}{|c|}{ Malaysia } \\
\hline & GDP* & 6219.755 & 1339.622 & 1.141 & 4.643 & $\mathrm{P}<0.05$ & 0.421 \\
\hline & internet & -50.131 & 23.01 & -0.535 & -2.179 & 0.102 & \\
\hline
\end{tabular}

* $\log$ transformed.

Standardized regression coefficients are presented in Table 4 to explain the importance of two predictors in predicting the number of publications. Independent variable with a high beta coefficient is highly important in contributing to the prediction of the number of total publications. Based on the beta values obtained, the beta coefficient in theworld's top university was -0.408 and -0.297 for GDP and 0.423 and 0.425 for Internet usagebetween 1993-2002 and 2003-2012, respectively. This means that Internet usagehad a much more significant influence than the GDP in predicting the number of publications. The results showedthe same issuefor ASEAN universities meaning thatin these two decades, Internet usagehad much more significant effects than the GDP in predicting the number of publications. Interestingly, GDP had more power (1.141) than the number of internetusers (-0.535) from 2003 to 2012 in predicting the number of publications in top ten Malaysian universities.

\section{Discussion and Conclusion}

In this study, a comparisonwas made among the top university in each ASEAN country, top ten Malaysian universities and the world's top universitiesregarding the relationship between economic growth and internet usagewithpublication productivity from 1993 to 2002 and 2003 to 2012. Shanghai Ranking (ARWU) was used to determine the top ten universities in the world as it is the first global ranking of universities to be publishedand one of the three most influential and widely observed international university rankings. Moreover, the numbers of publications were used to find the first university in each ASEAN country and top ten Malaysian universities because most of these universities were not listed in the ARWU, QS, or the Times Higher Education World 
University Rankings.

Publication productivity is an indicator of research output and could be used to rank countries and universities (Yazit and Zainab, 2007, Narin and Hamilton, 1996, Toutkoushian et al., 2003, Liu and Cheng, 2005, Meho and Spurgin). It can also be used to determine author's productivity or the publication productivity of research groups and to assess the productivity of persons in a particular discipline (Liu and Cheng, 2005, Hart, 2000, Uzun, 2002, Gu and Zainab, 2001, Fox, 1983, Yi et al., 2008). World's best universities are mostly working on physics andastronomy. Institutes whichare working in these fields could publish more papers and get more citations. They could publish $144.2 \%$ and $709.5 \%$ more papers comparedto ASEAN universities in Nature and Science journals, respectively (see Table 1). They could alsoreceive 9.8 times more citations per week for their most cited papers (see Table 1).

Table 5. ANOVA table

1993

\begin{tabular}{|c|c|c|c|c|c|c|c|}
\hline \multicolumn{8}{|c|}{ ANOVA $^{\text {b }}$} \\
\hline group & Model & & Sum of Squares & $\mathrm{df}$ & Mean Square & $\mathrm{F}$ & Sig. \\
\hline \multirow[t]{3}{*}{ world } & 1 & Regression & $1.756 \mathrm{E} 7$ & 2 & 8781193.216 & 12.390 & $.000^{\mathrm{a}}$ \\
\hline & & Residual & $6.875 \mathrm{E} 7$ & 97 & 708732.439 & & \\
\hline & & Total & $8.631 \mathrm{E} 7$ & 99 & & & \\
\hline \multirow[t]{3}{*}{ asean } & 1 & Regression & $1.656 \mathrm{E} 7$ & 2 & 8279590.609 & 52.212 & $.000^{\mathrm{a}}$ \\
\hline & & Residual & $1.126 \mathrm{E} 7$ & 71 & 158575.023 & & \\
\hline & & Total & $2.782 \mathrm{E} 7$ & 73 & & & \\
\hline \multirow[t]{3}{*}{ my } & 1 & Regression & 57700.227 & 2 & 28850.113 & 3.281 & $.042^{\mathrm{a}}$ \\
\hline & & Residual & 853014.813 & 97 & 8793.967 & & \\
\hline & & Total & 910715.040 & 99 & & & \\
\hline
\end{tabular}

a. Predictors: (Constant), internet, log GDP.

b. Dependent Variable: total publication.

2003

\begin{tabular}{|c|c|c|c|c|c|c|c|}
\hline \multicolumn{8}{|c|}{ ANOVA $^{\mathrm{b}}$} \\
\hline group & Model & & Sum of Squares & df & Mean Square & $\mathrm{F}$ & Sig. \\
\hline \multirow[t]{3}{*}{ world } & 1 & Regression & $5.958 \mathrm{E} 7$ & 2 & 2.979E7 & 17.996 & $.000^{\mathrm{a}}$ \\
\hline & & Residual & $1.440 \mathrm{E} 8$ & 87 & 1655372.703 & & \\
\hline & & Total & $2.036 \mathrm{E} 8$ & 89 & & & \\
\hline \multirow[t]{3}{*}{ asean } & 1 & Regression & $9.489 \mathrm{E} 7$ & 2 & $4.745 \mathrm{E} 7$ & 50.153 & $.000^{\mathrm{a}}$ \\
\hline & & Residual & $7.379 \mathrm{E} 7$ & 78 & 946035.347 & & \\
\hline & & Total & $1.687 \mathrm{E} 8$ & 80 & & & \\
\hline \multirow[t]{3}{*}{ my } & 1 & Regression & $2.040 \mathrm{E} 7$ & 2 & $1.020 \mathrm{E} 7$ & 33.387 & $.000^{\mathrm{a}}$ \\
\hline & & Residual & $2.658 \mathrm{E} 7$ & 87 & 305522.329 & & \\
\hline & & Total & $4.698 \mathrm{E} 7$ & 89 & & & \\
\hline
\end{tabular}

a. Predictors: (Constant), internet, log GDP.

b. Dependent Variable: total publication. 
Publication trendfrom 1993 to 2012 in ASEAN and top ten Malaysian universitieswith 20.9 and $65.5 \%$ growth ispromising compared to the world's top ten universities (1.9\%). ASEAN and Malaysian universities havebeen averagely established over the past 66 and 37 years ago, respectively; while the top universities in the world have been averagely stabilised 327 years ago. This can be one of the reasons of high trend in publication productivity in ASEAN and Malaysian universities. In addition, the growth of publications might be overestimated due to the omitted variables, and a reverse causality from GDP to publications will be another possibility to occur.The number of publications in Malaysia increased dramatically after 2007 to 2012 (almost 5 times) (see Appendixes 1 and 2). One of the main reasons for increasing the number of paper publications in Malaysia could be greatly concentrating on enhancing the quality of research in the universities which are specific for researching like University of Malaya. Specified in the 10th Malaysia Plan, $1 \%$ of Malaysia GDP will be spent on the development and research projects. Furthermore, the other important reason could be the change of dissertations direction from conventional into research-based. $\mathrm{PhD}$ students have enhanced 10 times in the past years (there were about 4000 students in 2002, while they have increased to 40,000 in 2012). The top ten universities in Malaysia are shown in Table 1. It should be mentioned that the first five universities shown are ranked as the research universities and get more government funding.

Thefindings of this study showed a positive and significant correlationbetween GDP and the number of publications in ASEAN and Malaysian universities. This finding was in line withthe findings of previous research studies that showedpositive and significant correlationbetween education and economic growth (Mankiw et al., 1992; Barro, 1991; Bils and Klenow, 2000). Interestingly, there is a negative and significant correlation between the number of publications (articles and letters) and economic growth in top ten Malaysian universities from 1993 to 2012. Besides, Jin and Jin showed in their recent study that the publication productivity affect the economic growth differently in various fields.In top ten universities located in the United States and United Kingdom, GDP could not have positive effects to increase the number of publications. While the significant effects of GDP on the number of publications were seen in Malaysian universities especially from 2003 to 2012.

However, it should be noted that only the effects of GDP and internet usageon publications of recent years were evaluated in this study. Since the educational effects are accomplished over longer horizons, further investigation of the educational effects using the data that correspond to the stock of publications in earlier years would be important.

Science managers and policy makers in ASEAN countries shouldspend much more percentage of their GDP on development and research projects as Malaysia does.Moreover, increasing the number of PhD students and changing the universityprograms to paper-based dissertations could be another solution to increase the number of publications. Furthermore, it is necessary to find out different ways to improve the quality and visibility of theresearch studiesand invest more on research studies that their outputs lead to more rapid economic growth.

\section{References}

Barro, R. J. (1991). Economic growth in a cross section of countries. The Quarterly Journal of Economics, 106, 407-443. http://dx.doi.org/10.2307/2937943

Becker, G. S. (2009). Human capital: A theoretical and empirical analysis, with special reference to education. University of Chicago Press.

Bils, M., \& Klenow, P. J. (2000). Does schooling cause growth? American Economic Review, 1160-1183. http://dx.doi.org/10.1257/aer.90.5.1160

Falagas, M. E., Pitsouni, E. I., Malietzis, G. A., \& Pappas, G. (2008). Comparison of PubMed, Scopus, web of science, and Google scholar: Strengths and weaknesses. The FASEB Journal, 22, 338-342. http://dx.doi.org/10.1096/fj.07-9492LSF

Fox, M. F. (1983). Publication productivity among scientists: A critical review. Social Studies of Science, 13, 285-305. http://dx.doi.org/10.1177/030631283013002005

Gu, Y., \& Zainab, A. (2001). Publication productivity of Malaysian researchers in the field of Computer Science and Information Technology. Malaysian Journal of Library \& Information Science, 6, 1-23.

Hart, R. L. (2000). Co-authorship in the academic library literature: A survey of attitudes and behaviors. The Journal of Academic Librarianship, 26, 339-345. http://dx.doi.org/10.1016/S0099-1333(00)00140-3

Jin, J. C., \& Jin, L. (2013). Research publications and economic growth: Evidence from cross-country regressions. Applied Economics, 45, 983-990. http://dx.doi.org/10.1080/00036846.2011.613785 
Joynt, R. L., \& Leonard, J. A. (1980). Dantrolene sodium suspension in treatment of spastic cerebral palsy. $\begin{array}{lllll}\text { Developmental Medicine } \quad \& \quad \text { Child } & \text { Neurology, } & 22, & 755-767 .\end{array}$ http://dx.doi.org/10.1111/j.1469-8749.1980.tb03742.x

Kelly, J., Glynn, R., O’briain, D., Felle, P., \& Mccabe, J. (2010). The 100 classic papers of orthopaedic surgery a bibliometric analysis. Journal of Bone \& Joint Surgery, British Volume, 92, 1338-1343. http://dx.doi.org/10.1302/0301-620X.92B10.24867

Lefaivre, K. A., \& O'brien, P. J. (2011). 100 most cited articles in orthopaedic surgery. Clinical Orthopaedics and Related Research ${ }^{\circledR}, 469,1487-1497$. http://dx.doi.org/10.1007/s11999-010-1604-1

Liu, N. C., \& Cheng, Y. (2005). The academic ranking of world universities. Higher education in Europe, 30, 127-136. http://dx.doi.org/10.1080/03797720500260116

Lucas, Jr, R. E. (1988). On the mechanics of economic development. Journal of monetary economics, 22, 3-42. http://dx.doi.org/10.1016/0304-3932(88)90168-7

Mankiw, N. G., Romer, D., \& Weil, D. N. (1992). A contribution to the empirics of economic growth. The Quarterly Journal of Economics, 107, 407-437. http://dx.doi.org/10.2307/2118477

Meho, L. I., \& Spurgin, K. M. (2005). Ranking the research productivity of lis faculty and schools: An evaluation of data sources and research methods. Journal of the American Society for Information Science and Technology, 56(12), 1314-1331.

Narin, F., \& Hamilton, K. S. (1996). Bibliometric performance measures. Scientometrics, 36, 293-310. http://dx.doi.org/10.1007/BF02129596

Nelson, R. R., \& Phelps, E. S. (1966). Investment in humans, technological diffusion, and economic growth. The American Economic Review, 56, 69-75.

Ponce, F. A., \& Lozano, A. M. (2010). Highly cited works in neurosurgery. Part I: the 100 top-cited papers in neurosurgical journals: A review. Journal of neurosurgery, 112, 223-232. http://dx.doi.org/10.3171/2009.12.JNS091599

Romer, P. M. (1990). Endogenous technological change. Journal of political Economy, S71-S102. http://dx.doi.org/10.1086/261725

Sarel, M. (1997). Growth and productivity in ASEAN countries. International Monetary Fund.

Toutkoushian, R. K., Porter, S. R., Danielson, C., \& Hollis, P. R. (2003). Using publications counts to measure an institution's research productivity. Research in Higher Education, 44, 121-148. http://dx.doi.org/10.1023/A:1022070227966

Uzun, A. (2002). Productivity ratings of institutions based on publication in Scientometrics, Informetrics, and

Bibliometrics, 1981-2000. Scientometrics, 53, 297-307. http://dx.doi.org/10.1023/A:1014864827441

Yazit, N., \& Zainab, A. (2007). Publication productivity of Malaysian authors and institutions in LIS. Malaysian Journal of Library and Information Science, 12.

Yi, H., Ao, X., \& Ho, Y. S. (2008). Use of citation per publication as an indicator to evaluate pentachlorophenol research. Scientometrics, 75, 67-80. http://dx.doi.org/10.1007/s11192-007-1849-y

Zain, Z. M., Ishak, R., \& Ghani, E. K. (2009). The influence of corporate culture on organisational commitment: A study on a Malaysian listed company. European Journal of Economics, Finance and Administrative Sciences, 17, 16-26.

\section{Copyrights}

Copyright for this article is retained by the author(s), with first publication rights granted to the journal.

This is an open-access article distributed under the terms and conditions of the Creative Commons Attribution license (http://creativecommons.org/licenses/by/3.0/). 